\title{
KISRUH LAPORAN KEUANGAN : BAGAIMANAKAH KINERJA KEUANGAN PT GARUDA INDONESIA TBK?
}

\author{
Listika Nuri $^{1}$, Sri Andriani ${ }^{2}$ \\ ${ }^{1 *}$ Fakultas Ekonomi \& Bisnis Universitas Teknologi Sumbawa \\ 2Fakultas Ekonomi \& Bisnis Universitas Teknologi Sumbawa \\ *Corresponding Author email: 1listika.nuri@gmail.com, ${ }^{2}$ sri.andriani@uts.ac.id
}

\begin{tabular}{|c|c|}
\hline & Abstrak \\
\hline Diterima: & Garuda Indonesia Tbk merupakan perusahaan penerbangan terbaik yang ada di Indonesia. \\
\hline Bulan Juni 2021 & $\begin{array}{l}\text { Namun kisruh laporan keuangan Garuda Indonesia Tbk yang terjadi pada tahun } 2018 \\
\text { menyebabkan menurunnya kinerja keuangan yang tercermin pada harga saham }\end{array}$ \\
\hline Diterbitkan: & perusahaan tersebut. Penelitian ini dilakukan untuk mengetahui kinerja keuangan Garuda \\
\hline Bulan Juli 2021 & $\begin{array}{l}\text { Indonesia Tbk dilihat dari pengaruh rasio likuiditas (current ratio) terhadap harga saham } \\
\text { perusahaan dengan rasio profitabilitas (return on asset) sebagai variabel intervening. }\end{array}$ \\
\hline Keyword: & Hasil penelitian menunjukkan bahwa rasio likuiditas berpengaruh terhadap harga saham \\
\hline Kisruh Lapo & Garuda Indonesia. Namun rasio likuiditas tidak berpengaruh terhadap profitabiltas \\
\hline Keuangan, & perusahaan. Selain itu, rasio profitabilitas juga tidak berpengaruh signifikan terhadap \\
\hline Likuiditas, & harga saham. Terakhir, rasio profitabilitas tidak mampu memediasi pengaruh antara rasio \\
\hline $\begin{array}{l}\text { Profitabilitas, } \\
\text { Harga Saham }\end{array}$ & likuiditas terhadap harga saham Garuda Indonesia Tbk. \\
\hline
\end{tabular}

\section{PENDAHULUAN}

Garuda Indoesia Tbk adalah satu-satunya badan usaha milik negara (BUMN) yang melayani penerbangan domestik dan internasional. Oleh karena itu, Garuda Indonesia selalu berusaha untuk memberikan pelayanan terbaik untuk meningkatkan kinerjanya terutama kinerja keuangan.

Menurut (CNN, 2019) kinerja keuangan PT Garuda Indonesia (Persero) yang berhasil membukukan laba bersih US\$809 ribu pada 2018, berbanding terbalik dari 2017 yang merugi US\$216,58 juta menuai polemik. Pencatatan kerugian berhasil diselamatkan dari satu perjanjian kerja sama dengan dengan PT Mahata Aero Teknologi (MAT) bernilai US\$239,94 juta atau setara Rp 3,41 triliun (kurs Rp 14.200/US\$).

Dua komisaris Garuda Indonesia, Chairul Tanjung dan Dony Oskaria menolak untuk mendatangani laporan keuangan 2018. Keduanya menolak pencatatan transaksi kerja sama penyediaan layanan konektivitas (wifi) dalam penerbangan dengan PT Mahata Aero Teknologi (Mahata) dalam pos pendapatan. Pasalnya, belum ada pembayaran yang masuk dari Mahata hingga akhir 2018. (CNN, 2019)

Kisruh yang terjadi menyebabkan penurunan kinerja perusahaan baik secara internal maupun eksternal Garuda Indonesia. Selain itu juga menyebabkan menurunnya kepercayaan masyarakat terhadap perusahaan. Dikutip dari (Katadata, 2019), kinerja Garuda Indonesia Tbk selama beberapa tahun terakhir mengalami fluktuasi, hal ini secara ringkas digambarkan pada gambar di bawah ini.

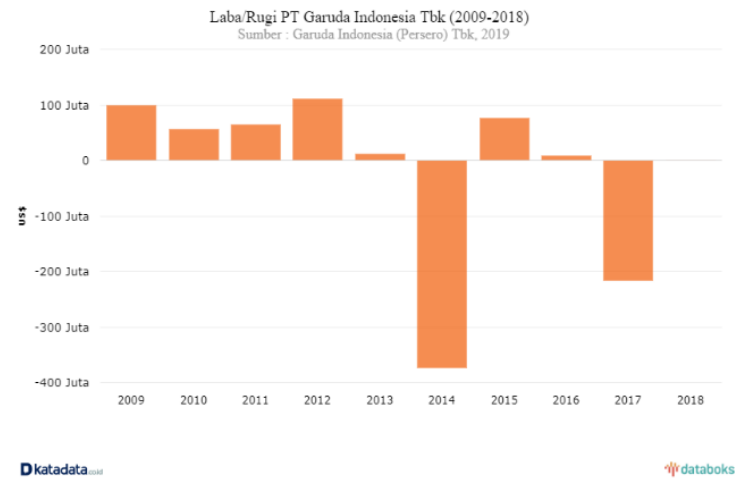

Gambar 1. Laba/Rugi PT Garuda Indonesia Tbk Periode 2009-2018

Beberapa tahun terakhir, ginerja keuangan Garuda Indonesia terlihat lebih sering menghasilkan keuntungan, kecuali pada tahun 2013 dan 2017. Terutama kisruh yang terjadi pada tahun 2018 berakibat pada timbulnya sentimen negative dari investor yang berakibat turunnya harga saham Garuda Indonesia. Hal ini akan berakibat pada menurunnya kinerja perusahaan yang tergambar pada rasio keuangan (likuiditas dan profitabilitas). Menurut (Nurfianti \& Wulansari, 2021), likuiditas yang diwakilkan oleh current ratio berpengaruh signifikan terhadap return on asset (ROA) pada perusahaan PT Indocement Tunggal Prakarsa Tbk. Demikin juga hasil penelitian (Muslih, 2019) mengatakan bahwa current ratio berpengaruh signifikan terhadap return on asset (ROA).

Harga saham di pasar modal merupakan refleksi dari semua informasi yang tersedia. Berbagai peristiwa yang terjadi di lingkungan pasar modal, baik lingkungan ekonomi maupun non- 
ekonomi, memiliki kandungan informasi yang digunakan sebagai dasar pengambilan keputusan bagi investor sehingga menjadi salah satu faktor yang menentukan naik turunnya harga saham. Fluktuasi harga saham merupakan hal penting yang menjadi perhatian bagi para investor karena harga saham mencerminkan kinerja perusahaan. (Mangindaan \& Manossoh, 2020)

Salah satu faktor yang mempengaruhi harga saham adalah return on asset (ROA). ROA menggambarkan kemampuan perusahaan menghasilkan keuntungan atau laba dilihat dari jumlah asset yang dimiliki (Brigham \& Houston, 2014). Menurut (Hendra, 2019), ROA tidak berpengaruh terhadap harga saham perusahaan di industri penerbangan. Namun, di penelitian lain mengatakan bahwa ROE berpengaruh positif dan signifikan terhadap harga saham perbankan di Indonesia (Ady, 2021).

Selain ROA, current ratio (CR) juga mempengaruhi harga saham perusahaan. CR merupakan gambaran kemampuan perusahaan (aktiva lancar) dalam memenuhi kewajiban jangka pendeknya (Husnan, 2014). Dalam penelitian yang dilakukan oleh (Nurlia \& Juwari, 2019) mengatakan bahwa CR mempunyai pengaruh yang sangat kuat terhadap harga saham perusahaan.

\section{LANDASAN TEORI \\ Kinerja Keuangan}

Kinerja keuangan menurut (Mamduh M. Hanafi, 2015) adalah gambaran mengenai tingkat pencapaian pelaksanaan suatu kegiatan dalam mewujudkan sasaran, tujuan, misi dan visi strategic planning. Kinerja keuangan dapat digunakan untuk mengetahui sejauh mana perusahaan sudah menggunakan aturan keuangan secara baik dan benar (Fahmi, 2017).

\section{Analisis Rasio Keuangan}

Rasio keuangan merupakan alat analisis untuk menjelaskan hubungan tertentu antara elemen yang satu dengan elemen yang lainnya dalam suatu laporan keuangan. Menurut (Subramanyam \& Wild, 2012) Analisis rasio keuangan adalah bagian dari analisis bisnis atas prospek dan risiko perusahaan untuk kepentingan pengambilan keputusan dengan menstrukturkan tugas analisis melalui evaluasi atas bisnis lingkungan perusahaan, strateginya, serta posisi dan kinerja keuangannya.

Menurut (Mamduh M. Hanafi, 2015), ada lima jenis rasio keuangan yang sering digunakan, meliputi: rasio likiditas, rasio aktivitas, rasio utang/laverage, rasio keuntungan/profitabilitas, dan rasio pasar. Pada penelitian ini hanya menggunakan rasio likuiditas dan rasio profitabilitas.

\section{Likuiditas}

Likuiditas merupakan alat untuk mengukur sejauh mana perusahaan dapat memenuhi kewajiban jangka pendeknya. (Mamduh $\mathrm{M}$.
Hanafi, 2015) memaparkan bahwa likuiditas merupakan alat ukur perusahaan dalam memenuhi utang jangka pendeknya.

Menurut (Mamduh M. Hanafi, 2015), rasio lancar adalah rasio untuk mengukur kemampuan perusahaan utang jangka pendeknya (jatuh tempo kurang dari satu tahun) dengan menggunakan aktiva lancar. Rasio yang tinggi menunjukan kelebihan aktiva lancar (likuiditas tinggi dan risiko rendah) tetapi memiliki pengaruh yang tidak baik terhadap profit perusahaan. Aktiva lancar secara umum menghasilkan return dan tingkat keuntungan yang lebih rendah dibandingkan dengan aktiva tetap. Namun rasio yang tinggi menunjukan likuiditas jangka pendek yang rendah.

$$
\text { Current Ratio }=\frac{\text { Asset Lancar }}{\text { Kewajiban Lancar }}
$$

\section{Profitabilitas}

Rasio profitabilitas yaitu rasio untuk mengukur tingkat efektifitas pengelolaan perusahaan yang ditunjukan oleh jumlah keuntungan yang dihasilkan dari penjualan dan investasi. Menurut (Mamduh M. Hanafi, 2015), rasioprofitabilitas adalah "rasio yang mengukur kemampuan perusahaan dalam menghasikan keuntungan pada tingkat penjualan, asset, dan modal saham yang telah ditentukan.

Semakin besar ROA yang dimiliki suatu perusahaan maka semakin efisien pengguna aktiva sehingga akan memperbesar laba. ROA yang tinggi menunjuan efesiensi dan efektivitas pengelolaan asset yang semakin baik (Mamduh M. Hanafi, 2015). Laba yang besar akan menarik investor karena perusahaan memiliki tingkat pengembalian yang semakin tinggi, sehingga menarikminat para investor untuk membeli saham,sehingga harga harga saham akan naik.

\section{Harga Saham}

$$
\text { Return on Asset }=\frac{\text { Laba Bersih }}{\text { Total Asset }} \times 100 \%
$$

Harga Saham adalah harga suatu saham pada pasar yang sedang berlangsung di Bursa Efek. Harga Saham dapat dipengaruhi oleh situasi pasar antara lain harga saham dipasar perdana ditentukan oleh penjamin emisi dan perusahaan yang akan go public (emiten), berdasarkan analisis fundamental perusahaan. Peranan penjamin emisi pada pasar perdana selain menentukan harga saham, juga melaksanakan penjualan saham kepada masyarakat sebagai calon pemodal.

Menurut (Halim, 2005), harga saham merupakan harga jual beli yang sedang berlaku di pasar efek yang ditentukan oleh kekuatan pasar dalam arti tergantungan pada kekuatan permintaan (penawaran) dan penawaran (permintaan jual). Harga saham juga menunjukkan nilai dari perusahaan itu sendiri. Semakin tinggi nilai dari harga pasar saham suatu perusahaan, maka investor akan tertarik untuk menjual sahamnya. Bursa saham 
merupakan salah satu indicator perekonomian suatu negara maka diperlukan suatu pertimbangan tentang transaksi yang terjadi dalam bursa sepanjang periode tertentu.

Harga saham yang diharapkan oleh investor adalah harga saham yang stabil dan mempunyai pola pergerakan yang cenderung naik dari waktu ke waktu, akan tetapi kenyataan yang ada harga saham cenderung berfluktuasi. Oleh karena itu investor harus memahami hal apa saja yang dapat mempengaruhi berfluktuasinya harga saham. Fluktuasi harga saham secara fundamental dipengaruhi oleh kinerja perusahaan dan kemungkinan risiko yang dihadapi .

Nilai pasar saham dipengaruhi oleh faktor yang langsung dan tidak langsung. Nilai saham dapat berubah setiap saat, tergantung kondisi pasar, persepsi investor terhadap perusahaan, informasi yang berkembang atau isu lain yang menerpa pasar modal.

\section{Faktor yang Mempengaruhi Harga Saham}

Menurut (Brigham \& Houston, 2006), faktor-faktor yang mempengaruhi harga saham meliputi:

1. Laba per lembar saham (Earning Per Share/EPS)

2. Tingkat Bunga

3. Jumlah Kas Deviden yang Diberikan

4. Jumlah laba yang didapat perusahaan

5. Tingkat Risiko dan Pengembalian

Sedangkat menurut (Alwi, 2008), ada beberapa faktor yang mempengaruhi pergerakan harga saham atau indeks harga saham, antara lain:

1. Faktor Internal (Lingkungan mikro). Misalnya pengumuman tentang pemasaran, produksi, penjualan seperti pengiklanan, rincian kontrak, perubahan harga, penarikan produk baru, laporan produksi, laporan keamanan produk, dan laporan penjualan

2. Faktor eksternal (lingkungan makro). Misalnya Pengumuman dari pemerintah seperti perubahan suku bunga tabungan dan deposito, kurs valuta asing, inflasi, serta berbagai regulasi dan deregulasi ekonomi yang dikeluarkan oleh pemerintah.

Gejolak politik dalam negeri dan fluktuasi nilai tukar jugamerupakan factor yang berpengaruh signifikan pada terjadinya pergerakan harga saham di bursa efek suatu negara.

\section{MATODE PENELITIAN \\ Jenis Penelitian}

Jenis penelitian yang digunakan adalah kuantitatif dengan pendekatan kausal. Penelitian kuantitatif adalah dengan mengumpulkan data berupa data maupun angka atau data berupa katakata atau kalimat yang dikonversi menjadi data yang berbentuk angka (Sugiyono, 2016).
Penelitian kausal merupakan penelitian yang memiliki hubungan yang bersifat sebab akibat jadi sini ada variabel eksogen yang mempengaruhi dan variabel endogen yang dipengaruhinya (Sugiyono, 2016).

\section{Populasi dan Sempel}

Populasi dalam penelitian ini adalah laporan keuangan triwulan PT. Garuda Indonesia Tbk yang terdaftar dan sudah dilaporkan di Bursa Efek Indonesia periode 2013-2019.

Sedangkan sampel diambil menggunakan metode non probability sampling dimana teknik pengambilan sempel yang tidak memberi kesempatan/peluang sama bagi setiap unsur atau anggota populasi untuk dipilih menjadi sampel dengan tipe metode sampling jenuh dan purposive sampling.

Sampling jenuh merupakan teknik pengumpulan sempel dimana semua anggota populasi menjadi sempel penelitian. Kriteria sampel pada penelitian ini yaitu laporan keuangan triwulan pertama pada tahun 2013 hingga triwulan terakhir pada tahun 2019 yang tetap dipublikasikan melalui situs www.idx.co.id

\section{Teknik Analisis Data}

Pada penelitian ini peneliti menggunakan model struktural (Structural Equation Model atau SEM) untuk menguji model penelitiannya. SEM menggambarkan hubungan kausal terhadap variable-variabel yang diteorikan, variabel yang diposisikan sebagai penyebab awal disebut eksogen dan variabel yang diposisikan sebagai akibat disebut endogen.

Pada penelitian ini, model penelitian diuji menggunakan pendekatan Partial Least square (PLS). PLS merupakan model persamaan Struktural Equation Modeling (SEM) berbasis komponen maupun varian. PLS merupakan faktor indeterminacy metode analisis yang power full karena tidak didasarkan pada banyak asumsi (Ghozali, 2014). SEM-PLS adalah analisis persamaan struktural berbasis varian yang secara simultan dapat melakukan pengujian model pengukuran (outer model) dan pengujian model struktural (inner model) yang dimana model pengukuran digunakan untuk uji validitas dan reliabilitas dan model struktural digunakan untuk uji kausalitas (Ghozali, 2014).

Model reflektif mengasumsikan bahwa konstruk atau variabel laten mempengaruhi indikator (arah hubungan kausalitas darikonstruk ke indikator/manifest). Variabel laten dapat juga dibentuk oleh indikatorindikator yang bersifat formatif yang mengasumsikan bahwa indikatorindikator mempengaruhi konstruk (arah hubungan kausalitas dari indikator ke konstruk) (Ghozali, 2014). Berikut adalah tahapan-tahapan yang 
dilakukan dalam menganalisis menggunakan SEMPLS :

1. Merancang Inner Model dan Outer Model

2. Mengontruksi diagram jalur

3. Konversi diagram jalur ke persamaan

4. Parameter Estimasi

5. Evaluasi Goodness of Fit (GoF)

6. Hipotesis

\section{HASIL DAN PEMBAHASAN}

Merancang Inner Model dan Outer Model

Pengujian model struktural (Inner Model) bertujuan untuk mengetahui pengaruh korelasi atau hubungan kausalitas dari setiap variabel independen dan variabel dependen serta pengaruh tidak langsung antar variabel independen dan variabel dependen yang dimediasi oleh variabel intervening. Dalam penelitian ini hanya akan membahas mengenai model structural (inner model). Berikut ini merupakan tabel Inner Model :

Tabel 1. Inner Model

\begin{tabular}{|l|l|l|l|}
\hline & $\begin{array}{l}\text { Harga } \\
\text { Saham }\end{array}$ & Likuiditas & Profitabilitas \\
\hline Harga Saham & & & \\
\hline Likuiditas & 1 & & 1 \\
\hline Profitabilitas & 1 & & \\
\hline
\end{tabular}

Sumber : Data diolah, 2020

Dengan melihat tabel diatas dapat disimpulkan bahwa likuditas mempengaruhi harga saham sebanyak satu kali dan mempengaruhi profitabilitas sebanyak satu kali, profitabilitas hanya mempengaruhi harga saham saja sebanyak satu kali, sedangkan harga saham tidak dapat mempengaruhi karna harga saham selaku variabel yang dipengaruhinya.

\section{Mengontruksi Diagram Jalur}

Setelah merancang Inner Model selanjutnya kita mengontruksikan menjadi diagram jalur. Berikut ini hasil mengontruksikan rancangan Inner model menjadi diagram jalur:

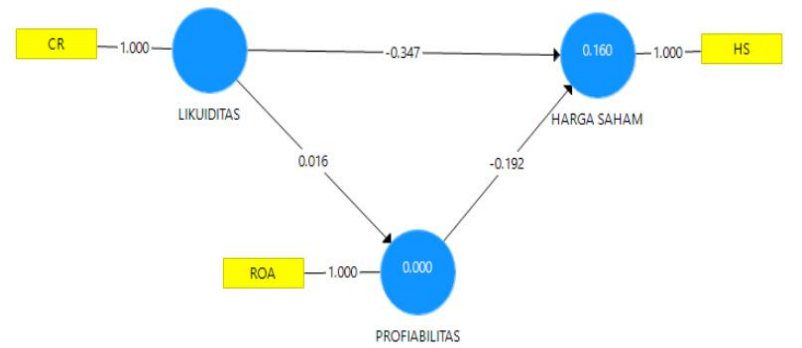

Gambar 2. Diagram Jalur

\section{Parameter Estimasi}

Parameter estimasi yang dilakukan pada model pengukuran dan structural dalam PLS, berikut adalah nilai R-Square sebagai berikut :

Tabel 2. Hasil R Square

\begin{tabular}{|l|l|}
\hline & R Squre \\
\hline Harga Saham & 0,160 \\
\hline Profitabilitas & 0,000 \\
\hline
\end{tabular}

Sumber : Data diolah, 2020

Tabel di atas menunjukkan nilai R-Square 0.000 untuk konstruk profitabilitas yang berarti bahwa likuiditas tidak mampu menjelaskan profitabilitas. Dalam artian sisanya sejumlah $100 \%$ dipengaruhi oleh variabel lain. Sedangkan harga saham menunjukkan nilai R-Square 0.160 yang berarti bahwa likuiditas dan profitabilitas mampu menjelaskan harga saham sebesar $16 \%$. Sisanya $84 \%$ adalah variabel lain diantaranya, nilai tukar, suku bunga, dan lain-lain yang mempengaruhi harga saham.

\section{Evaluasi Goodness of Fit}

Analisis Goodness of Fit (GoF) digunakan untuk mengetahui apakah model hasil analisis cukup baik untuk menjelaskan fenomena yang dikaji. Dari hasil analisis GoF model diperoleh dari nilai QSquare:

$$
\begin{aligned}
Q 2 \quad & =1-(1-R 12)(1-R 22) \ldots(1-R p 2) \\
& =1-(1-0.000)(1-0.160) \\
& =1-(1.000)(0.840) \\
& =1-0.840 \\
& =0.160 \\
& \text { Hal ini mengindikasikan bahwa dari }
\end{aligned}
$$
perhitungan statistik, maka model sudah baik, variasi variabel yang terlibat dalam model telah mampu menjelaskan variabel- variabel yang mempengaruhi harga saham sebesar $16 \%$. Sisanya $84 \%$ merupakan faktor lain yang turut mempengaruhi harga saham, termasuk di dalamnya adalah error.

\section{Evaluasi Pengujian Hipotesis: Bootstrapping}

$$
\text { Kemudian dilakukannya prosedur }
$$
bootsrapping untuk mendapatkan nilai yang digunakan sebagai evaluasi model. Model struktural dalam PLS dievaluasi dengan menggunakan Rsquare untuk variabel dependen dan nilai koefisien pada path untuk variabel independen yang kemudian dinilai signifikansinya berdasarkan nilai t-statistik setiap path. Untuk nilai signifikansi model prediksi dalam pengujian model struktural, dapat dilihat dari nilai t-statistik antara variabel independen ke variabel dependen dalam path coefficient pada output SmartPLS (Jogiyanto, \& Abdillah, 2009).

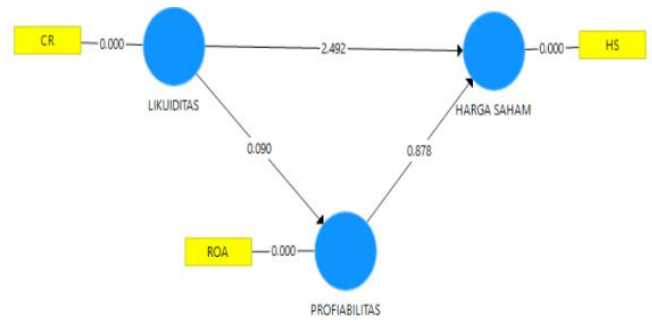

Gambar 3. Diagram Jalur Setelah Bootstrapping 
Tabel 3. Path Coeffisients (Mean, STDEV, T-

\begin{tabular}{|l|l|l|l|l|l|}
\hline & $\begin{array}{l}\text { Orig. } \\
\text { Sample } \\
(\mathrm{O})\end{array}$ & $\begin{array}{l}\text { Mean } \\
(\mathrm{M})\end{array}$ & $\mathrm{SD}$ & $\begin{array}{l}\mathrm{T} \\
\text { Stat. }\end{array}$ & $\mathrm{PV}$ \\
\hline $\begin{array}{l}\text { Likuiditas- } \\
\text { Harga Saham }\end{array}$ & $-0,347$ & $-0,332$ & 0,139 & 2,492 & 0,013 \\
\hline $\begin{array}{l}\text { Likuiditas- } \\
\text { Profitabilitas }\end{array}$ & 0,016 & 0,024 & 0,184 & 0,090 & 0,929 \\
\hline $\begin{array}{l}\text { Profitabilitas- } \\
\text { Harga Saham }\end{array}$ & $-0,192$ & $-0,215$ & 0,219 & 0,878 & 0,380 \\
\hline $\begin{array}{l}\text { Likuiditas- } \\
\text { Profitabilitas- } \\
\text { Harga Saham }\end{array}$ & $-0,003$ & $-0,016$ & 0,064 & 0,049 & 0,961 \\
\hline
\end{tabular}

Sumber : Data diolah, 2020

Uji t dilakukan pada tingkat kepercayaan 95\%. Hipotesis diterima jika t-hitung lebih besar dari ttabel. T-tabel tingkat keyakinan 95\% dengan nilai alpha 5\% adalah 1.98472. Berdasarkan nilai tstatistik pada tabel 4.5 dapat diuji hipotesis sebagai berikut:

\section{Pengaruh Likuiditas terhadap Harga \\ Saham}

Berdasarkan tabel 3 diatas, dapat disimpulkan bahwa Likuiditas berpengaruh secara langsung terhadap profitabilitas. Dimana nilai t hitung (2.492) lebih besar dari t table (1.985) dan nilai signifikansi (0.013) lebih kecil dari 0.05. Dari hasil tersebut juga dapat disimpulkan bahwa likuiditas berpengaruh signifikan terhadap harga saham dengan koefisien pengaruh sebesar 0.437. semakin tinggi nilai likuiditas (CR) maka mengindikasikan bahwa perusahaan mampu memenuhi kewajiban jangka pendeknya. Hal ini memberikan signal positif terhadap investor sehingga dapat meningkatkan nilai perusahaan (harga saham) Hanafi, 2015.

Hasil penelitian ini sesuai dengan penelitian yang dilakukan oleh (Darmawan, 2018) dan (Syawalina \& Harun Fahlevi, 2020) yang mengatakan bahwa likuiditas $(C R)$ berpengaruh terhadap harga saham perusahaan.

2. Pengaruh likuiditas terhadap profitabilitas

Pengaruh Likuiditas terhadap profitabilitas berdasarkan tabel di atas dapat disimpulkan bahwa likuiditas tidak berpengaruh signifikan terhadap profitabilitas. Dimana nilai t hitung (0.090) lebih kecil dari $\mathrm{t}$ tabel (1.985) dengan nilai signifikansi (0.929) lebih besar dari 0.05. Dari hasil tersebut dapat disimpulkan bahwa likuiditaas berpengaruh signifikan terhadap pofitabilitas dengan koefisien pengaruh sebesar 0.016 .

Likuiditas mencerminkan kemampuan perusahaan memenuhi kewajiban jangka pendeknya. Semakin tinggi nilai likuiditas maka semakin baik. Namun di sisi lain, tingginya nilai dari likuiditas juga mengindikasikan bahwa terdapat banyak asset lancar perusahaan yang menganggur yang seharusnya dapat digunakan untuk menghasilkan keuntungan yang lebih optimal.
Sehingga dalam pnelitian ini likuiditas tidak berpengaruh terhadap harga saham.

Sejalan dengan hasil penelitian ini (Suwandi, Thalia, Syakina, Munawarah, \& Aisyah, 2019) dan (Napitupulu, 2019) mengatakan bahwa likuiditas (CR) tidak berpengaruh terhadap profitabilitas (ROA) perusahaan.

\section{Pengaruh Profitabilitas terhadap Harga Saham}

Tabel di atas menunjukkan nilai $\mathrm{t}$ hitung (0.878) lebih kecil dari $t$ table (1.985) yang berarti profitabilitas tidak berpengaruh signifikan terhadap harga saham, dengan nilai signifikansi sebesar (0.380) lebih besar dari 0.05. Tabel diatas juga menunjukkan pengaruh profitabilitas dengan harga saham dengan nilai koefisien pengaruh nya sebesar $(-0.192)$.

Selain dipengaruhi oleh tingkat keuntungan (factor internal), harga saham juga dipengaruhi oleh faktor eksternal. Misalnya kondisi ekonomi negara, inflasi,atau isu-isu lain yang dapat menimbulkan sentiment negative terhadap harga saham. Hasil ini sesuia dengan penelitian yang dilakukan oleh (Utami \& Darmawan, 2018), (Pangaribuan \& Suryono, 2019) dan (Al umar \& Nur Savitri, 2020) yang mengatakan bahwa ROE tidak berpengaruh terhadap harga saham.

\section{Pengaruh Likuiditas terhadap Harga Saham melalui Profitabilitas sebagai Variabel Intervening}

Tabel di atas menunjukan nilai t hitung sebesar (0.049) lebih kecil dari t tabel yaitu (1.985) yang berarti likuiditas tidak berpengaruh signifikan terhadap harga saham melalui profitabilitas sebagai variabel intervening dengan nilai signifikansi sebesar (0.961) lebih besar dari (0.05). Pada tabel diatas juga menunjukan pengaruh likuiditas terhadap harga saham melalui profitabilitas sebagai variabel intervening dengan nilai koefisen pengaruhnya sebesar $(-0.003)$.

(Mardian \& Sanusi, 2017) dan (Manurung \& Nainggolan, 2020) mengatakan bahwa variabel profitabilitas tidak mampu memediasi pengaruh antara likuiditas terhadap harga saham.

\section{PENUTUP \\ Kesimpulan}

Kinerja keuangan merupakan salah satu indicator untuk menilai kondisi keuangan perusahaan. Garuda Indonesia sebagai perusahaan BUMN selalu berusaha memberikan kinerja terbaik bagi para stake holder. Namun, kisruh laporan keuangan lapa tahun 2018 menyebabkan penurunan harga saham perusahaan "burung besi" tersebut.

Jika dilihat dari kondisi likuiditas menunjukkan bahwa rasio likuiditas berpengaruh terhadap harga saham Garuda Indonesia. Namun rasio likuiditas tidak berpengaruh terhadap profitabiltas perusahaan tersebut. Selain itu, rasio profitabilitas juga tidak berpengaruh signifikan 
terhadap harga saham Garuda Indonesia. Terakhir, rasio profitabilitas tidak mampu memediasi pengaruh antara rasio likuiditas terhadap harga saham Garuda Indonesia Tbk.

\section{REFERENSI}

Ady, R. A. (2021). Analisis Pengaruh Rasio Keuangan Terhadap Harga Saham Pada Perusahaan Perbankan Yang Terdaftar Di Bursa Efek Indonesia Periode 2016-2018. Media Akuntansi, 33(01). https://doi.org/10.47202/mak.v33i01.114

Al umar, A. U. albab, \& Nur Savitri, A. S. (2020). Analisis Pengaruh Roa, Roe, Eps Terhadap Harga Saham. Jurnal Analisa Akuntansi Dan Perpajakan, $4(2)$. https://doi.org/10.25139/jaap.v4i2.3051

Alwi, I. Z. (2008). Pasar Modal Teori dan Aplikasi. In Yayasan Pancur Siwah.

Brigham, E. F., \& Houston, J. F. (2006). DasarDasar Manajemen Keuangan (ed.10). In Salemba Empat.

Brigham, E. F., \& Houston, J. F. (2014). DasarDasar Manajemen Keuangan Edisi 11 Buku 1. In Salemba Empat Jakarta.

CNN. (2019). Kronologi Kisruh Laporan Keuangan Garuda Indonesia. CNN Indonesia, p. 390927. Retrieved from https://www.cnnindonesia.com/ekonomi/201 90430174733-92-390927/kronologi-kisruhlaporan-keuangan-garuda-indonesia

Darmawan, A. N. (2018). Analisis Pengaruh Profitabilitas, Likuiditas Dan Pertumbuhan Penjualan Perusahaan Terhadap Harga Saham Dengan Struktur Modal Sebagai Variabel Intervening Pada Perusahaan Manufaktur Di Bursa Efek Indonesia. Jurnal Ilmu Manajemen, 4(2). https://doi.org/10.31328/jim.v4i2.557

Fahmi, I. (2017). Analisis Kinerja Keuangan Panduan bagi Akademisi, Manajer, dan Investor untuk Menilai dan Menganalisis Bisnis dari ASpek Keuangan. In $C V$ ALFABETA.

Ghozali, I. (2014). Model Persamaan Struktural. Konsep dan Aplikasi Dengan Program AMOS 22.0. In Model Persamaan Struktural. Konsep dan Aplikasi Dengan Program AMOS 22. Update Bayesian SEM.

Halim, A. (2005). Analisis Investasi. Edisi Kedua. In Salemba Empat.

Hendra, D. (2019). Pengaruh Debt To Equity Ratio (Der), Current Ratio (Cr), Return On Asset (Roa) Dan Return On Equity (Roe)Terhadap Harga Saham Dan Implikasinya Terhadap Return Saham Pada Industri PENERBANGAN (Studi Kasus Pada Perusahaan Maskapai Asia). KREATIF: Jurnal Ilmiah Prodi Manajemen Universitas Pamulang, https://doi.org/10.32493/jk.v7i1.y2019.p8092

Husnan, S. (2014). Manajemen Keuangan Teori dan Penerapan (Keputusan Jangka Panjang). In None.

Jogiyanto, \& Abdillah, W. (2009). Konsep dan Aplikasi PLS (Partial Least Square) untuk Penelitian Empiris. Yogyakarta: BPFE.

Katadata. (2019). Bagaimana Kinerja Garuda Indonesia dari Tahun ke Tahun? Katadata. Retrieved from https://databoks.katadata.co.id/datapublish/20 19/07/08/bagaimana-kinerja-garudaindonesia-dari-tahun-ke-tahun\#

Mamduh M. Hanafi. (2015). Analisis Laporan Keuangan. Edisi. 4. Analisis Keuangan.

Mangindaan, J. V., \& Manossoh, H. (2020). Analisis Perbandingan Harga Saham PT Garuda Indonesia Persero (Tbk.) Sebelum dan Sesudah Pandemi Covid-19. JURNAL ADMINISTRASI BISNIS (JAB), 10(2), 80-85. https://doi.org/10.35797/jab.10.2.2020.31281 .80-85

Manurung, S., \& Nainggolan, C. D. (2020). Profitabilitas Sebagai Variabel Intervening Atas Pengaruh Likuiditas Terhadap Harga Saham. ... (Jurnal Penelitian Ilmu ....

Mardian, A. F., \& Sanusi, F. (2017). Pengaruh Likuiditas Terhadap Harga Saham Dengan Profitabilitas Sebagai Variabel Intervening Pada Perusahaan Manufaktur Sektor Aneka Industri Yang Terdaftar Di Bei Periode 20132016. Tirtayasa Ekonomika, 12(2). https://doi.org/10.35448/jte.v12i2.4455

Muslih, M. (2019). Pengaruh Perputaran Kas Dan Likuiditas ( Current Ratio ) Terhadap Profitabilitas ( Return on Asset ). Kumpulan Riset Akuntansi, 11(1).

Napitupulu, R. D. (2019). Determinasi Efisiensi Modal Kerja Dan Likuiditas Terhadap Profitabilitas Pada Perusahaan Sektor Farmasi Yang Terdaftar Di Bei. Jurnal Akuntansi Bisnis, 12(1). https://doi.org/10.30813/jab.v12i1.1508

Nurfianti, S., \& Wulansari, R. (2021). Pengaruh Debt To Asset Ratio Dan Current Ratio Terhadap Return On Asset Pada PT Indocement Tunggal Prakarsa Tbk Periode 2010-2019. Jurnal Ilmiah Mahasiswa (JIMAWA), 1(1). https://doi.org/10.32493/jmw.v1i1.9684

Nurlia, N., \& Juwari, J. (2019). Pengaruh Return On Asset, Return On Equity, Earning Per Share Dan Current Ratio Terhadap Harga Saham Pada Perusahaan Sub Sektor Otomotif Dan Komponen Yang Terdaftar Di Bursa Efek Indonesia. Jurnal GeoEkonomi, 10(1). https://doi.org/10.36277/geoekonomi.v10i1.5 0 
Pangaribuan, A. A., \& Suryono, B. (2019). Pengaruh ROA, ROE, DAN EPS Terhadap Harga Saham Perusahaan Transportasi di BEI. Ilmu Dan Riset Akuntansi, 8(5).

Subramanyam, \& Wild, J. J. (2012). Subramanyam dan John J. Wild. 2012. Analisis Laporan Keuangan. Jakarta: Salemba Empat. Jakarta: Salemba Empat.

Sugiyono. (2016). Metodologi Penelitian Kuantitatif, Kualitatif, dan R\&D. In $C V$ Alfabeta.

Suwandi, S., Thalia, J., Syakina, S., Munawarah, M., \& Aisyah, S. (2019). Pengaruh Rasio Aktivitas, Solvabilitas dan Likuiditas Terhadap Profitabilitas pada Perusahaan Pertambangan Batubara. Journal of Education, Humaniora and Social Sciences
(JEHSS),

l(3). https://doi.org/10.34007/jehss.v1i3.42

Syawalina, C. F., \& Harun Fahlevi, T. R. (2020). Pengaruh Likuiditas, Profitabilitas, Dan Ukuran Perusahaan Terhadap Harga Saham Pada Perusahaan Sektor Makanan Dan Minuman Yang Terdaftar Di Bursa Efek Indonesia. Jurnal Akuntansi Muhammadiyah, 10(2). https://doi.org/10.37598/jam.v10i2.843

Utami, M. R., \& Darmawan, A. (2018). Pengaruh Der, Roa, Roe, Eps Dan Mva Terhadap Harga Saham Pada Indeks Saham Syariah Indonesia. Journal Of Applied Managerial Accounting, 2(2). https://doi.org/10.30871/jama.v2i2.910 